Published in BRITISH EDUCATIONAL RESEARCH JOURNAL 31(2):157-183 Apr 2005

DOI: $10.1080 / 0141192052000340198$

Alis Oancea, University of Oxford, Department of Educational Studies

\title{
Criticisms of Educational Research: Key topics and levels of analysis ${ }^{1}$
}

\begin{abstract}
The article is an exploration of the meanings and worthiness of criticism as a significant phenomenon in the evolution of educational research during the 1990s. While drawing on an overview of the vast amount of documents expressing criticisms of educational research in the UK, western and eastern continental Europe and the USA, it summarises the findings of a study based on the analysis of some of the most influential texts that criticised educational research in the UK during the mid-1990s: Hargreaves (1996), Tooley \& Darby (1998), Hillage et al. (1998). An understanding of the targets, sources, solutions and actors that are characteristic of the recent criticisms of educational research is proposed, together with an exploration of the rhetorical devices employed in expressing criticism and of some of the philosophical themes that underpin the recent debates.
\end{abstract}

\footnotetext{
${ }^{1}$ A much earlier draft of this paper was presented to the British Educational Research Association annual conference, Edinburgh, September 2003 (Oancea, 2003a. See also Oancea, 2004).
} 


\section{Background and aims}

In the 1990-s, most major educational journals and many handbooks of research methodology in the United Kingdom and abroad hosted extensive debates on the (questioned) quality of educational research. The critical stances expressed the dissatisfaction of almost all the groups directly involved with educational research: practitioners, decision-makers, researchers. From "laissez-faire" (Homan, 1990) and "problematic" (Bassey, 1992), in the early nineteen nineties, educational research in Britain got to be called a mere "irrelevance and distraction" (Woodhead, 1998), "in a sorry state" (Ball, 1995) and nothing more than "sloppy" (Tooley \& Darby, 1998) "ivory-towerism" (Blunkett, 2000) by 2000. The late nineties have seen at least two discourses emerge and consolidate, one lamenting the misbehaviour of educational research from a managerial perspective (associated with a "big science" model of knowledge production and an "engineering" model of knowledge use), and the other attempting to defend it in the name of academic freedom and right to diversity, or to reinstate it through a humanistic model of knowledge transfer. Such allegedly antagonistic discourses about educational research are the focus of a variety of conference papers, journal editorials or book reviews - see Furlong, 2004; Smith and Hodkinson, 2002; Stronach, 2001; Stronach and Hustler, 2001; Thomas, 1998; Stronach, Allan and Morris, 1996. The role of the educational researcher is conceptualised differently, from that of a "technician" meant to deliver answers to "what works"-like questions, to that of a "public" or "critical" intellectual whose accountability should be defined not in terms of the immediate impact of national policies informed by research findings, but as a capacity to producing localized, transferable knowledge (Furlong, 2004; Fuller, 1999; Goodson, 1999; Mortimore, 2000; Ball, 1995; Gibbons et al., 1994; Harlen, 1994). Nonetheless, a worry is present that some rather anachronistic "paradigm wars" (Yates, 2004; Hammersley, 1992; Anderson and Herr, 1999) threaten to be rekindled by pushing forward some ad-hoc "folk 
devils" (Lomax, 1999) or by "getting the ghosts out to repeat themselves" (Stronach and Hustler, 2001, p. 523), and therefore that often the deeper complexities of the matter and their philosophical underpinnings remain outside the epicentre of the debate.

The British Educational Research Journal closely echoed the clash of arguments about the overall quality and impact of educational research. The articles published over the nineties, as well as the British Educational Research Association (BERA) Presidential Addresses that opened nearly every new volume of the journal from 1990 to 2000, cover most of the highly disputed topics around which the debate grew, such as: the difficulties of the profession of educational researcher (Mortimore, 2000; Bridges, 1998; Brown, 1998; McIntyre, 1997; Simons, 1995; Harlen, 1994; Gipps, 1993); the use and limitations of systematic reviews of research or of the idea of evidence-based/informed policy and practice (Evans and Benefield, 2001; Hammersley, 2001; Elliott, 2001; Hammersley, 1997; Hargreaves, 1997); the ownership of the research agenda and the issue of researchers' accountability (and in relation to this, the problems generated by the current procedures for the distribution of funding, including here the Research Assessment Exercise - RAE) (Lomax, 1999; Goodson, 1999; Mc Intyre, 1997; Brine, 1997; Pirrie, 1997; Gipps, 1993; Hammersley and Scarth, 1993; Homan, 1990; McNamara, 1990); and the evaluation of educational research given the diversity of research communities (Lomax, 1999; McIntyre, 1997; Stronach, Allan and Morris, 1996; Homan, 1990). The concept recurrently used to describe the current situation of both educational research and the debate about its quality was "crisis", be it a moral crisis; a crisis of legitimation (Lomax, 1999) of the community of educational research; a crisis of positionality (Goodson, 1999) of educational research in the broader political and socio-economical context; or, more optimistically, a growth crisis generated by the fragile balance between the underdevelopment of educational research and its "brilliant possibilities" (Edwards, 2002, p.167). The October 2003 special issue "In Praise 
of Educational Research" addresses the criticisms of the 1990s, while seeking "to celebrate some of the best recent education research" (Gorard \& Taylor, 2003,p. 619).

A glance over the vast amount of documents that criticised educational research in the 1990s (journal articles, newspaper articles, official publications, conference proceedings etc.) suggests that criticism varies in intensity, focus, and means of expression, and that such variation occurs over time, but also across countries, organisational structures, involvement with research, methodological commitments within research paradigms, and so forth. A question emerges about the patterns of this variation, together with their conditions and impact. Such question calls for a comparative overview of the types of criticisms expressed across geographical and organisational settings, disciplinary frameworks and time spans.

However, the attempts at summarizing and building an account of criticism itself, as a significant phenomenon for the evolution of educational research in the 1990-s, are not very numerous and they are often confined to a sub-heading in a journal article or in a book chapter (see Hamilton, 2002; Hammersley, 2002; Pring, 2000a, 2000b; Sylva, 2000; Wellington, 2000; Ranson, 1998). A project along these lines would have to rely, therefore, on multidisciplinary studies, drawing on literary theory, linguistics, sociolinguistics, policy research, cultural studies or social psychology. For instance, some starting points could be offered by studies of literary criticism (see Baldick, 1996), of social construction of scientists' discourse (Gilbert and Mulkay, 1984), and of rhetorical - argumentational and stylistical organisation of discourse (Billig, 1996; van Dijk, 1997), if criticism is to be interpreted as a species of discourse; but also by studies of blaming and defending behaviour or of verbal interaction (Edwards and Potter, 1992), if criticism is to be defined in terms of action/interaction. Nonetheless, the insights of the philosophy of science/ philosophy of research provide useful tools for an understanding of the underlying philosophical frameworks of criticism. I am referring here to philosophical traditions that value reflexive critical attitude as central to the development of research, such as: the idea of 
criticism and of critical attitude as a necessary means for theoretical advancement (Lakatos \& Musgrave, 1974); the challenge of traditional research from less conventional standpoints (making way for the voices of the marginalised, hindered, excluded: critical theory, feminist and anti-racist studies), or the challenge of established patterns of discourse, revealing the complexity and "ungraspability" of the text-context interplay (postmodernist and poststructuralist writings). Finally, expressions of criticism in other fields of research (e.g., medicine, psychiatry, counselling, law) might offer a counterpoint to the study of criticism of educational research. For example, the British Medical Journal (vol. 310-312, 1995-1997) devoted much space to debates about evidence-based medicine, its arguments and the associated critiques of medical research (which was sometimes taken as a model by critics of educational research - see Hargreaves, 1996, 1997).

This paper attempts to identify main topics, themes and rhetorical features that were characteristic of the criticisms of educational research in Britain over the 1990s. The concept of criticism that will be employed throughout this paper relies on its predominant use within the documents analysed (and hence the apparent emphasis on the negative bearings of criticism, despite an etymologically justifiable strand of more neutral or positive meanings, such as judgement, assessment or investigation). The intentions sketched above are consistent with the aims of a broader research project, which is focused on the recent and international tendency to be critical of educational research, in an attempt to grasp the meanings of the recent criticisms across geographical, organizational, temporal and disciplinary settings and to explore their significance for shaping the policies and practice of research and for structuring the community of researchers itself. A definition of criticism is only to be sought at the end of such project, for it has to be built up through the exploration of its various instantiations and properties. 


\section{Methodological considerations and data sources}

The nature of the problem to be investigated and of the aims briefly stated above suggest a methodological approach that takes advantage of the heuristic possibilities of textual analysis while combining features from rhetorical discourse analysis, the grounded theory approach, and relational content analysis in a mixture of quantitative and qualitative techniques. Nonetheless, the research design retains certain openness, meant to allow space for its development alongside the analysis. The sampling/ data collection and the analysis are intertwined: further collected data throw new lights over the analytic findings, whereas the outcomes of the analysis orient subsequent sampling towards issues that need to be explored in more detail. In this study, I retain the importance of the openness and sensitivity to data, as put forward in the grounded theory perspective, but I try to combine these with a quasi-external set of descriptive categories and analytic foci (along the lines of rhetorical discourse analysis - see van Dijk, 1997, vol. 1-2) and with some quantitative linguistic evidence. The following specialised computer software packages were selected to assist the different stages of the analysis: Atlas/ti for managing the primary documents, coding, and building code networks; WordSmith Tools, for word lists, collocations, frequencies and comparisons with larger English corpora; and SPSS, for basic quantitative analyses.

In doing so, I use an extensive selection of newspaper articles, academic journals, books and official documents (from governmental organisations, quangos and non-governmental organisations) as a fundamental source of data, but some of the vast amount available of "grey literature" expressing criticisms of educational research (conference papers, theses, ongoing research projects, on-line publications and discussion lists) are also taken into account. For comparative purposes, this selection covers different agents (researchers, policy-makers, teachers, journalists, general public, both as individuals and as collective agents); settings 
(United Kingdom, United States of America, Western Continental Europe, Eastern and Central Europe); time spans (the periods immediately before 1990 and after 2000 are considered alongside the main period 1990-2000); and fields of enquiry (focus on educational research, but with a glimpse to medicine and sociology).

As part of this broader study, the present paper illustrates the research process and the emerging findings through reference to a narrower range of documents (semi/official materials) consisting of some of the most cited British papers that were critical of educational research during the mid-nineties, a period when the upsurge of criticism reached the public arena with high intensity. For example, in 1998 only, about 60 newspaper articles were published on the alleged "irrelevance", "waste of public money" and "low quality" of educational research (for a detailed analysis of the newspapers' coverage of the criticisms of educational research after 1990, see Oancea, 2003b). The three documents analysed in Section 4 of this paper are:

1. Hargreaves, D. H. (1996) Teaching as a Research Based Profession: possibilities and prospects. Teacher Training Agency (TTA) Annual Lecture (London, TTA).

2. Tooley, J. \& Darby, D. (1998) Educational Research. A Critique. A survey of published educational research (London: Office for Standards in Education - OFSTED).

3. Hillage, J.; Pearson, R.; Anderson, A. \& Tamkin, P. (1998) Excellence in Research on Schools. Research Report No. 74. (London: Department for Education and Employment DfEE; Sussex: Institute for Employment Studies).

Certainly, these documents are not the beginning of the criticist trend, but it could be said that they set the tone for a vast amount of literature on the topic (see Section 3). The Social Sciences Citation Index Expanded, searched on 13/11/2003 for journal articles in English that cite any of the three papers selected over the time span 1996-2003, returned the following: D. Hargreaves' Lecture: 45 citations (of which 51\% between 1996-2000); J. Tooley \& D. Darby 
report: 53 citations (of which 38\% between 1998-2000); J. Hillage et al. report: 33 citations (of which 55\% between 1998 and 2000).

The reactions that the afore-mentioned documents have stimulated included (mostly) defensive viewpoints in academic journals (see Hammersley, 1997, 2000); projects for "improving educational research" (and therefore implicitly accepting the current criticisms), especially from governmental sources and from collective bodies that have undertaken the maintaining of the "standards and co-ordination" of research (such as the National Foundation for Educational Research - NFER; BERA; the Economic and Social Research Council - ESRC; the Department for Education and Skills - DfES; later on, the National Educational Research Forum - NERF); and attempts to summarise patterns of the criticism in order to reach some more productive syntheses and a deeper understanding of the premises of the debate (e.g. Pring, 2000b; Carr, 2000; Oxford Review of Education, vol. 26, issues 3-4, 2000; or, the Presidential Addresses to the BERA, published in the British Educational Research Journal). Some were also wary of an emerging politically orthodox standpoint vis-à-vis research. This standpoint overemphasised the direct impact of research with policy and practice, the reviewing and assessment of research, and the concept of accountability, and thus it might threaten to impoverish alternative approaches to research (Hamilton, 2002; Smith, 2001; Hodkinson, 2000; Sylva, 2000). Such reactions were followed by new responses and so forth, gradually building a web of references and commentaries, apparently marked by patterns of clashing arguments. It is this intricate network that I intend to explore.

Coding the various instances of criticism raised specific problems, given the intricacy of themes and the mixture of political and philosophical assumptions underlying them. The way I first approached the documents has some common features with the coding strategies suggested by the proponents of the grounded theory approach to text analysis (Glaser and Strauss, 1967; Strauss and Corbin, 1998). However, this approach, as described in its basic texts, is meant to act 
as a general guideline or heuristic starting point, and not as a rigorously structured procedure, and this is how I understand its relevance for my research.

I started by browsing the documents and identifying a few striking phrases and words that would give the flavour of what was going on. For instance, each document begins with a statement of intentions, which includes a list of the topics that the authors aim to cover. I focused therefore my first reading on the concepts the authors employ in developing these declared topics. With the technical support of Atlas/ti I did a line-by-line analysis of the documents. Thus I obtained a large list of rather discrete concepts (“open coding”- Strauss and Corbin, 1998, p. 101) and also an unstructured file of notes and comments ("memos"), which I had written while planning my analysis and during the first coding sessions.

However, what I really was after was the conceptual network that would organise these words and phrases in a meaningful description/ explanation of the kind of criticism deployed in the documents analysed. Browsing through my memos, I began to see possible groupings of concepts and possible patterns in the data. The more paragraphs I coded, the clearer some of these groupings became; so I proceeded to the merging of certain codes and to the hierarchical organisation of others (“axial coding” - Strauss and Corbin, 1998, p. 123). The networks of concepts, as presented in Section 4 of this paper, have emerged from the analysis of the sample of "crucial" documents listed above and they get constantly enriched once different types of documents, from different types of agents and different contexts are introduced in the analysis. This is the search for variation that guides the next stages of my research.

In the process of merging and organising the codes, new categories gradually emerged that described the texts analysed on three fundamental levels: a topics level, much along the lines of the topics stated explicitly by the authors themselves; a rhetoric level (discursive features of the texts, including issues of argumentation, management of audience and style); and a thematic level, as a pool of presuppositions that underpin the previous two. At each level, I was able to 
find a constellation of concepts that seemed to map the recent controversies about educational research. Nonetheless, while working towards the integration of the findings, it became clear that the analysis would benefit from the complementary use of some other analytic tools (such as quantification in terms of word collocations grouped around grammatical categories, or such as the use of "external" or "descriptive" categories to guide the study of the discursive features of the texts). For each level of the texts, a specific analytic approach seemed to be more appropriate: corpus linguistics and relational content analysis (for identifying the foci of criticism), rhetorical discourse analysis (for revealing the rhetorical devices employed), grounded theory (for the overall approach and the emergence of underlying themes). Therefore, a combination of these methodological approaches underlies the following findings and comments.

\section{A context of criticism}

The documents analysed here were published over a time span of only three years (19961998). For the reasons mentioned in the introductory parts of this paper, I consider them (and the reactions that they stimulated) fairly representative for the criticism of educational research in the United Kingdom, in the mid-nineties. However, they emerged on the background of a much broader (temporally and spatially) concern about educational research.

On the one hand, criticisms of educational research seem to have as long a history as educational research itself and certain themes are reiterated over time. The theme of the backwardness (in terms of scientificity or of disciplinary development) of educational research in comparison to other fields of study dates centuries back and it has never been exhausted. Some of the current arguments are easily recognizable, for instance, in A.W. Diesterweg's (1835) criticism of educational research (avant-la-lettre) in a period marked by the "academisation" of modern pedagogy (in the sense of "the study of education"). According to 
Diesterweg, the development of pedagogy had been slower than that of other sciences, who had left pedagogy far behind. This backwardness of pedagogy could be explained, suggested Diesterweg, both by imminent features of pedagogy (such as its dependence on philosophy, psychology and theology, and the difficulty of abstracting universal laws from the extremely high variability of educational systems) and by the problematic manner in which its inquiry has been conducted (for example, very rarely has a pedagogue met the essential requirements for good theorising in pedagogy, i.e. erudition as well as teaching experience) (Diesterweg, 1835). Some of the current debates replay such concerns, from new perspectives (see the theme of the underdevelopment of educational studies, Edwards, 2002; Hargreaves, 1996; McNamara, 1990).

On the other hand, in Britain, the second half of the last century saw some radical changes in the importance attributed to research by the successive governments. Furlong (2004) argues that, in the social democracy and political arithmetic of the 1960s and 1970s, certain strands of research tended to be taken very seriously, but this happened to the detriment of any other type of research; whereas during the 1980s' period of market competition and audit culture social research became altogether marginalized, and any criticisms faded accordingly.

Educational research entered thus the 1990s with a rather ambiguous status and experiencing convulsive attempts to negotiate its revised role within the changing political and global context. However, despite the apparent continuity of concerns about educational research throughout the 20-th century, there were prominent changes in the global context over the nineteen nineties the radical political changes, the explosion of new communication technologies, the effects of the postmodernist critique of "meta-narratives", to mention but a few-in relation to which the types of criticisms expressed could be expected to show corresponding particularities. This led to a shift in emphasis by the end of the 1990s, from criticising whatever aspects of research did not fit the managerial paradigm, to praising the diversity of epistemic communities and the role of educational researchers as critical intellectuals whose work has a long-term impact that goes 
beyond any immediate effects of delivering findings to inform policies (Foray and Hargreaves, 2002; Hargreaves, 2003; Furlong, 2004).

The criticism expressed by the three British documents analysed in Section 4 below draws upon this national climate of concern vis-à-vis educational research, which has been quite intensive over the past 10 years, covering almost all areas of the research process (see Section 4). For example, an enormous number of book chapters and of articles about educational research published in the British academic journals contained in their titles words like: "criticism", “critique”, "for/against”, “defence”, “crisis", "war”, "rethinking”, “assessing”, "standards, criteria", "guidelines, codes", "mistakes, threats, vagaries", "fallacies", "bias" and so on (here are just a few examples: Atkinson, 2000; Hargreaves, 1997; Hammersley, 1992; Elliott, 1990).

A very powerful incentive for criticism was the perceived failure of the outcomes of educational research to satisfy the intentions or the expectations of different agents involved. For instance, whilst policy-makers complained about not being provided with "findings" of research that would give straightforward answers to policy- and practice-related questions, the educational researchers were more worried about intrinsic aspects of the educational research process (such as the small-scaleness of educational research projects, the emphasis on qualitative to the detriment of quantitative research design, or the lack of longitudinal studies). Among other possible sources of criticism, the fragmentation of the researchers' community and of the research process according to the different philosophical and methodological positions adopted and the failure of inter-paradigmatic communication (sometimes manifested as anger or intolerance) were often referred to, sometimes in relation to conflicting political and social ideologies. In addition, the external requirements for research, including the assessment exercises, the systematic reviews, the reform programs, the funding agencies' criteria, the refereeing procedures etc., as well as the changes in education and in the broader context (such as the patterns of teacher training or the organisation of the public sector) fuelled even more 
intense criticisms. Nonetheless, the public debate itself, wherein attention was drawn upon the insufficiently evidence- supported assumptions that operated in educational practice, was a particularly favourable medium to the controversies. The main agents in the recent debates were the governmental representatives (OFSTED, DfES, NFER, EPPI, ESRC, TTA, other councils and agencies), the academics/ professional researchers (individually or through their professional associations: BERA, SERA etc.), the representatives of other fields of research, even though often only indirectly (the Cochrane Collaboration), the journalists and publishers, and the practitioners (less likely to be heard, given the difficulties of getting published).

Increasingly caustic remarks found thus their way into the debate right from the early 1990s: educational researchers ignore "the essential purpose of schooling” (McNamara, 1990, p. 255); "educational research in Britain is laissez-faire not only in comparison with... other disciplines, but also with... the U.S." (Homan, 1990, p. 239); "fundamental research is being neglected in favour of development focused on the government's changing priorities" (Gipps, 1992, p. 277); "educational research and policy-making is in crisis" (Gipps, 1993, p. 3); "educational studies is in a sorry state and in danger of becoming sorrier" (Ball, 1995, p. 256). A long trail of reports and articles pointed at various 'flaws' of educational research (e.g., Wrigley, 1976; Elliott, 1990; Bassey, 1992; Nisbet, 1995).

In the mid 1990-s, the recurrently caustic public interventions of the Chief Inspector for Schools, deliciously exploited by newspapers, created discomfort amongst British researchers and practitioners, regarding educational research conduct, funding and impact with practice and policy making. In addition, the Teacher Training Agency Annual Lecture given by Professor David Hargreaves from Cambridge in 1996 acted like a catalyst. The academic journals hosted a series of responses to Hargreaves's lecture; researchers were reacting, either by joining Hargreaves's in his virulent criticism or, in many cases, by shifting the burden of the accusations to some less status-threatening domains (e.g., to the so-called unwillingness of practitioners to 
base their own activity on evidence gathered by research, or to the poverty of dissemination mechanisms available) (see Hammersley, 1997; Reynolds, 1998; Edwards, 1998).

By the end of the 1990s, the opening phrases of some other articles suggested a general atmosphere of crisis, conflict and of high-stakes controversy: "educational research in Britain is currently under threat" (Hammersley, 1997, p. 141); "the battle lines are drawn" (Sylva, 2000, p. 293). Furthermore, passionate debates were carried on that focused on specific areas of research: school effectiveness research; race and ethnicity research; evidence-based policy and practice; research on assessment, on literacy, on class size; action research. Some of the criticisms expressed with regard to such specific areas were reiterated with reference to more general aspects of educational research. For instance, one can easily recognise broader concerns in the four strands of criticism against school effectiveness research, as summarised by Goldstein \& Woodhouse (2000): abuse by the Government; oversimplification of complex 'causalities'; reducing theory to a 'reification of empirical relationships'; or the overall 'poor quality' of research.

The publication of the three documents under consideration here also occurred in an international context of intense critical scrutiny of educational research. For instance, "Educational Researcher" (Journal of the American Educational Research Association - AERA) and the American Educational Research Association conferences in 1995-1998 hosted very direct criticisms and debates about the nature of educational research, its organisation and its relation to policy making (see Donmoyer, 1997). Nonetheless, in Continental Europe contexts, we find researchers expressing criticisms that were partly similar to the United States' (and British) concerns, while seemingly taking a more definite trend against the "means-ends" rationality that underlies some current criticisms of educational research, together with an emphasis on the institutionalisation of "sciences of education" as a disciplinary field (thus seeing the academisation of educational research less as a flaw and more as a "normalisation" of the 
discipline). The postmodern concept of "in-between"-ness was also brought into the discussion, as a counterbalance to the possible danger of disciplinary closure (see Keiner, 2001, p. 101; Hofstetter \& Schneuwly, 2000, p. 21).

On a different dimension, criticism of similar intensity also characterised the evolution of other disciplines in the 1990s: social sciences, medical studies, and even natural sciences. The paradigmatic case for educational research, given the frequency of the comparisons made (including here Hargreaves's TTA Lecture, 1996), was that of medicine. The inauguration of the Cochrane Collaboration in 1993 (following the opening of the first Cochrane Centre in Oxford, in 1992) has stimulated the interest in randomised control trials, systematic reviews of research and evidence-based practice, not only for the medical profession, but for the social research as well. Criticisms of the Cochrane Collaboration approach to research followed close to its success, especially in medical journals (see Carr-Hill, 1998; Court, 1996). This did not impede, though, the expansion of the corresponding network of Cochrane Centres, nor the inauguration of the Campbell Collaboration (2000) with a special interest for social and educational research. The web site of the EPPI Centre in the United Kingdom mirrors the one of the Cochrane Collaboration, in an attempt to systematically "finding out what is already known" (EPPI Centre, 2003). D. Hargreaves's (1996) critique of educational research explicitly stemmed from a comparison to medical research, which was taken to be more successfully oriented towards evidence-based practice; however, the rather strong criticisms of medical research itself in the 1990s have been the basis of many counter-attacks to Hargreaves's comments (e.g., Andersen, 1990; Altman, 1994).

\section{Topics, themes and rhetorical devices in the documents analysed}

As pointed out above, the analysis stretched out in three main directions: core topics/targets of criticisms; rhetorical devices for expressing criticism; and philosophical themes. The following paragraphs summarise the networks of concepts that emerged along each direction 
from the analysis of D. Hargreaves's TTA lecture (1996), J. Tooley and D. Darby's 1998 report to OFSTED, and J.Hillage and colleagues' 1998 report to the DfEE.

Firstly, there is a level of the topics that flesh out the debate over the quality of educational research. The three documents criticise almost all aspects of educational research:

- the commissioning of research. The procedures for funding were criticised for being unsystematic, politically biased and based on processes, such as peer reviewing, that would exclude users' input. Also, the choice of priorities was commented upon, as being misdirected, uncoordinated and supply-driven.

- the abilities, attitudes and practices of the actors involved. The researchers were deemed guilty of insufficient training and of partisanship in the conduct and presentation of research, in argumentation, in their choice of focus and priorities. Nonetheless, the practitioners and policy makers, at an individual and at a collective level, were also accused of being partisan and uncoordinated, lacking interest in research, lacking ability to use research findings, and thus not offering a strong user demand for research.

- the organisation of research was criticised at all levels: publication -inefficient refereeing procedures, pressure to publish; networking - lack of partnership, lack of user involvement, isolation of university researchers; monitoring - incoherent, internally driven, self-validating; dissemination -linear, not targeted and inefficient, correlated with a general lack of training for using research findings and a lack of mediation; and assessment -quantitative orientation of RAE, low standards, lack of codes of good practice.

- the methodology. Educational research was deemed non-reliable and inconclusive. Much of this was charged to flaws of empirical research, especially qualitative - lack of triangulation, sampling bias, purposeful distortion, ideological bias etc.; but also to flaws of non-empirical 
research, such as, contentiousness, superficial literature review, logical incoherence, excessive reliance upon secondary sources, adulation of great thinkers.

- the outcomes of research were criticised in terms of presentation (omissions in reporting; imprecision, emotional language, jargon, over-theoretical language etc.) and especially of impact of research (ineffectiveness in informing policy and practice, irrelevance for solving practical problems or for undertaken purposes, low contribution to any theoretical or methodological advancement, inaccessibility to audiences, non-cumulativity).

Secondly, I explored some rhetorical devices for putting forward political motifs and interests, which I found crucial in understanding the means of expressing criticism that were employed in the texts analysed. Different authors make similar points in different manners, in tight relation with contextual aspects, such as the professional and political status of the writer, the audience intended or the existing or presupposed counter-positions (see Section 4.1.). These 'games of power' create shifts of emphasis from one text to another, and the rhetoric employed reiterates an attack/defence cycle. The documents analysed employ a variety of rhetorical devices that can be categorised as follows:

- devices for building the critic's legitimacy and authority (i.e., the 'rhetorical persona', or how the critics define their status - for instance, as members of the research community, hence the use of 'we' when placing the blame about the low quality of research, or as decision-makers, citizens/taxpayers etc). Questions relevant here were: what type of individual characteristics the critics chose to put forward and to what types of support they resorted in order to enhance their credibility (e.g., emphasis on the validity and reliability of their own methods, or attempts to transfer authority from recognized experts to themselves); and how had they managed the variety of alternative epistemological and methodological commitments in the field, in other disciplines or in relation to the governmental standpoint. 
- devices for legitimising the criticism itself. Such devices were, for instance, the statement of the aims of criticism as a desirable activity, with the emphasis on its usefulness for the growth of knowledge, as an instrument of change, or as a regulating mechanism; and the stipulation of the properties of good criticism, such as 'informed', 'non-biased', or 'based on reasonable expectations'.

- devices for the management of the audience. The expected or assumed status and characteristics of the audience - e.g., the implied audience as partners, or as users/clients/beneficiaries of research- varied from one document to the other. As a consequence, a variety of techniques for co-interesting the audience were deployed, such as stressing common interests in education as a social service, in a good investment of taxpayers' money, or in addressing current policy issues. The register of language shifted accordingly, from informal, academic and technical, to managerial.

- offensive strategies were also deployed, in order to make the criticism expressed more compelling, to the detriment of any possible counter-arguments. Such devices involved the use of stylistic and grammatical tools to emphasise the amplitude and urgency of the debate (e.g., the 'hedging' of the positive statements by putting them in a secondary clause, and especially in a concessive clause, or by extensive use of modal verbs and adverbs; the choice of tropes; the use of comparison, especially comparison of educational research to other disciplines, such as medical research; the appeal to recognised authority through the use of quotations; the repetition of keywords and slogans; or the use of humour and irony).

Finally, some passages of the texts suggested a third layer, that of philosophical presuppositions that make the discourse much less neutral than it pretends to be (for the sake of gaining audience support). This layer indicates the methodological and philosophical rivalries between communities of educational research. Section 4.2 focuses on how the theme of the 
growth of knowledge is developed in the texts analysed. This is only one among a larger array of philosophical themes that will be left outside the scope of this paper. Such emerging themes are related to knowledge, truth, reality, and values, and further analytic efforts on this topic will need to explore them. Nonetheless, the theme that was chosen to illustrate the purposes of this paper the dynamics and growth of knowledge- is well covered in the three documents analysed here. I have grouped the findings around four pairs of concepts:

- cumulativeness of knowledge (body of knowledge, replication, dissemination, follow-up research, cross-disciplinary unity etc.) vs. non-cumulativeness (fragmentation, disciplinary rupture, diversity, paradigms, evolution, mutation, fashion);

- convergence (co-ordination, commensurability of viewpoints and norm sets, solidarity, centralisation -codes of practice, guidelines, quality control fora) vs. divergence in research (dispute and competition, incommensurability, decentralisation, independence);

- rationality (reasoning, logical design, evidence-based policy and practice, systematic design and advancement through systematic learning) vs. non-rationality of policy, practice and research (guess, intuition, revelation, emotionality, non-explicit experience, imitation); - teleology (fitness to purpose, especially in terms of improvement of practice, of existing knowledge and of professional status in the field, harmony, normativity, intentionality, shortterm, medium and long term planning) vs. non-teleology in research and in practice (functionality, deviation, unexpected outcomes, uncontrollable causal determinism). Some of these concepts were covered in the texts analysed here, while some others emerged from the various versions of counter-discourse (i.e. disapproving reactions, from a diversity of standpoints, to the types of criticisms that the documents analysed here triggered). Section 4.2. of this paper is a more detailed account of these findings.

Other knowledge-related issues have also emerged as relevant to the debate, but they will remain beyond the purpose of this paper. Such issues have to do, for instance, with the 
committment of the critics/counter-critics to empiricist or interpretivist traditions (Smith, 1989), to '(neo)-realist', 'hermeneutic relativist' or 'postmodernist' views about knowledge (Hodkinson, 1998, Smith and Hodkinson, 2002), to the pursuit of objectivity, in whatever way they might be conceptualised (Eisner, 1993, Hodkinson, 2000), or to method-centered procedures for establishing research truth (see Hodkinson, 2004, for further comments on this).

\subsection{The rhetoric of a new "orthodoxy"?}

At a first glance, despite the different approaches, the texts analysed seemed to be organised around three main categories: diagnosis (what is good and what is wrong about existing educational research); explanatory and mitigating circumstances (why did the 'wrong' part go wrong); and prescriptive statements of possible solutions (what to do about it). These categories are often overlapping, thus the repetitiveness of themes in the same text. Furthermore, the three documents differ in the attention they pay to each of these types of statements. For instance, while Hargreaves's lecture and the Hillage et al. report specifically focus on suggesting solutions for "the way forward", or on trying to find some explanatory variables or even mitigating circumstances (such as the lack of funding, time, encouragement, etc. for research), the Tooley \& Darby report does not spend much time on such recommendations, but extensively describes the shortcomings of published educational research. Furthermore, the rhetorical effect of the three texts varies with the shifts in the rhetorical persona (i.e., the authorial persona created in the rhetorical text, as different from the writer/speaker him-/herself) and in the implied audience (i.e., the 'fictive' audience that is "created by the text and exists only inside the symbolic world of the text", as distinctive from the 'real' audience; see van Dijk, 1997, vol. I, pp. 166-167).

The emerging criticism is construed around a series of motifs and slogans (i.e., phrases and words that occur above a certain frequency threshold in comparison to their corresponding 
frequencies in the British National Corpus of English, or/and that are placed in positions of grammatical or graphical emphasis within the texts), with high impact for the audience:

-“standards (model, criteria, codes) for good practice of research”, "value for money” (Tooley \& Darby, 1998)

-“ body of knowledge”, "research-based profession”, “evidence-based research”, "relevance for practice”, "user involvement”, “good value for money”, “national research strategy” (Hargreaves, 1996)

-“evidence-based policy and practice", "strategic coherence and partnership", "fitness for purpose”, "quality assurance”, “accessible language”, “excellence in research” (Hillage et al., 1998).

According to P. Hodkinson $(2004,2000)$, these kind of slogans would be nothing less than the indicator of a "new orthodoxy" in educational research, i.e. a framework of principles and attitudes that constitute the standards of acceptability for participating in the established system of commissioning and delivering research, with all the correspondent prestige and power games. From such a perspective, the three texts could be seen less as academic reports and more as political and propagandistic documents.

Let us take, firstly, the Hillage et al. Report (1998), which has the tone of an academic research report, trying to cover as many viewpoints as possible and to refrain itself from any exaggerated expression of criticism. The framework it promotes can be interpreted as a statement of the "new orthodoxy": wisely aware of the past fallacies, but projecting an optimistic future of a well-orchestrated research enterprise. The vocabulary of this vision would be meant to attract as many adherents as possible - and therefore a gain in image for the commissioning body (the Department for Education and Employment):

- verbs: “establish”, “set up”, “develop”, “encourage”, "improve”;

- $\quad$ adjectives: “clear”, “appropriate”, “systematic”, "regular”, “coherent”, “effective”;

- modals: "should", "need to", "have to";

- nouns: "strategy”, “evidence”, “commitment”, “support”, “co-ordination”, "monitoring”, “excellence”, “expertise”, “development”, “quality”, “impact”. 
The general repertoire is business-like and seasoned with technological (IT) metaphors, and thus well-tuned to a policy-making audience: "delivery of education”, "policy development/ implementation", “quality control/ assurance”, "strategies”, “infrastructure”, “supply”, "stakeholders", "the research production cycles", "target", "user", "transmission mechanisms", "competitive tendering", "outputs", "information unit(s)" and so forth. In addition, the rhetorical persona repeatedly shifts between impersonal implicit claims (“educational research has to..."), third person explicit claims (what the "respondents" said, especially in the first part of the summary, which includes most criticisms) and first person explicit claims ("we"- especially in the final part, consisting of recommendations). The summary ends on an impersonal note suggesting the imminence of change. The self-defining stance of the authors is that of objective external assessors who, despite being "relative outsiders to the world of educational research", nonetheless have "considerable experience" in social research, "some familiarity with the territory" and, most importantly, the capacity of acting free from any influence, further guaranteed by their " working in an independent, multidisciplinary research institute" (Hillage et al., p. 2). The keyword here is "independent", repeatedly emphasised in the report.

On the other hand, the Tooley \& Darby Report (1998), commissioned by OFSTED and prefaced by Chris Woodhead, the Chief Inspector for Schools at the time (Woodhead, 1998), takes a more clearly political standpoint, by focusing extensively on the problem of partisanship in research, e.g. "contentious and unsupported remarks about political reform" (p. 74 ), or "subjecting one government's reforms to critical scrutiny while at the same time accepting at face value previous educational reforms" (p. 74 ).

The vocabulary is a mixture of informal language, managerial language and methodological terms. It gains its expressivity from the use of litotes (the positive features of research being frequently introduced in an understated or negative form: "not all research was 
partisan in this way" -p. 74; "not all research showed these problems" - p. 74); of repetition ("partisan", "good practice", "standards"); of extreme quantifiers ("disturbingly large number of cases" - p. 74; "we found none" - p.75; "literally thousands of small-scale research projects"p. 78); or of risked comparisons ("it has been estimated that $£ 70$ million is spent on educational research per annum, of which about $90 \%$ is government funded.... This is not an insignificant amount - enough funds to employ 2,800 teachers, say, or to equip 70 secondary schools with a networked computer for every child" -p. 73).

While repeatedly insisting on the scientific standards of the Report and on the trustworthiness and possible extrapolation of their findings, the authors adopt a defensive stance, trying to minimise the possible objections to their methodological choices (i.e., selection of articles from "top" rated journals - p. 73, "distance" of researchers form the selection process and even from the judgements made -p. 74; the different philosophical and political persuasions of the two authors and their "considerable experience" -p. 27, 76). Similar self-legitimating purposes seem to be pursued through the reference to "good practice" as a manner of advertising the criticism. Even if initially they define themselves as educational researchers (through declaring their professional background and through the occasional use of "we" and "us" to cover "educational researchers"), as the report unfolds, they prefer a more impersonal voice, hence the very persistent use of passive constructions (e.g.: "this model was laid out", "it is hoped that...", "it can be said with reasonable confidence"). Consequently, they refer to “educational researchers" using third person, in a carefully cultivated distance: "the pressure to publish for the RAE could lead these academics to produce many small-scale...” (p. 79). The third person is also used for references to the audience: "the reader", "the people", "the university porter" who impersonates the somehow cheated mass of taxpayers. To summarise, the keywords for the rhetorical persona seem to be non-partisan researchers who present important findings arrived at by observing the standards of good practice. 
In contrast, D. Hargreaves' lecture (1996) doesn’t put forward any claims to being research-based. The mechanism of persuasion it relies on is mainly the expertise of a highly regarded academic concerned about the way "the teaching profession has ... been inadequately served by us" (p. 1), i.e. the educational researchers, and about the wrong paths "we" have chosen to follow. Hargreaves's attack is even more centred on the appealing image of a cumulative "body of knowledge" (p. 2), equipped with all the attributes of scientificity, as opposed to any postmodernist views on the dynamics of knowledge.

The vocabulary is often informal; taking into consideration that this is the only text of the three analysed here that was meant to be delivered orally, the familiar words and expressions serve to strengthen the image of an experienced, well-intended academic who is aware of the needs and difficulties of the teaching profession: "there is not a scrap of evidence" (p. 3); "educational research is caught between two stools" (p. 3); "one is tempted to shout a deeply sympathetic "snap"” (p. 3); "would be regarded by most colleagues as showing off” (p. 4), "hard cash is needed" (p. 7); "politicians who advocate their pet ideas" (p. 8). The effect is backed up through the use of organic metaphors, quite consistent with the core antithesis educational vs. medical research, around which the lecture is construed: "body of knowledge" (p. 2); "educational research is not in a healthy state" (p. 5); "the heart of any reform" (p. 6).

The initial oral delivery of this text also accounts for its being the only one that directly addresses the audience: "can any of you say that a parallel approach in teaching (...) would not be powerfully beneficial?" (p. 8). It is not a coincidence, from the perspective of the rhetorical effect, that the use of the second person pronoun intervenes towards the end of the lecture. This dramatic gradation of the text is sustained by the shifts in the meaning of "we" from "citizens" to "educational researchers" to "researchers, teachers and policy-makers" and finally to “connoisseurs" (including here the audience). 
The "way forward" that the three documents suggest is a projection of the new "good practice" of research. The documents recommend:

- clarification of the concepts;

- better command of methodology to prevent bias;

- training programs in educational research;

- intensifying participation of practitioners;

- promoting a stronger professional commitment;

- commitment to evidence-based development;

- changing the research agenda, with stronger involvement of "user communities", in a rather centralised forum;

- laying out a model for good research practice, with carefully designed and agreed criteria;

- elaborating policy documents and recommendations on enhancing partnership, quality, proper relation research- policy- practice;

- changing the funding procedures towards more focused ones;

- systematic reviews of research;

- changing the refereeing/ peer-review procedures (e.g., by making way for user involvement);

- creating structures for a better co-ordination and monitoring of research.

The "new orthodoxy", as it might appear from such a description, would seem to stand on some underlying common assumptions, such as:

a. educational research is necessary and valuable, despite its doubtful scientificity;

b. there are proper criteria for distinguishing science from non-science, good research from bad research;

c. educational research should not be an epigone of research as practised in other fields; 
d. even if controversial, the scientificity (or at least the quality) of educational research is worthwhile studying (and this justifies serious financial investments);

e. the quality of educational research can be improved through concerted (and often more centralised) efforts;

f. short and medium-term measures will stimulate this improvement;

g. the growth of a connected body of educational knowledge can be stimulated by measures that would counter the tendency towards fragmentation in research;

h. improvement of educational research and systematic reviews of its findings result in sounder (evidence-based) educational policy and practice.

This "seductive" but "problematic" "model of rational choice based on empirical research into the attainment of officially declared targets" (Pring, 2000b, p. 500) has its corresponding counter-positions, though far less cohesive and, before 2000, expressed on a more occasional basis, more openly in conferences and rather indirectly in journal articles. The following section of this paper explores some of the philosophical disagreements that underpin these contrasting standpoints, in an attempt to "deconstruct" their views on the fundamental issue of the growth of knowledge.

\subsection{Philosophical grounds of criticism - the growth of knowledge}

It has become rather commonsensical nowadays to assert that different philosophical and methodological standpoints of different authors lead to different interpretations of what educational research and its criticism are/ should be. The important thing however is not to assess all these perspectives from an impossible "God's eye" view (Putnam, 1981, p. 50), but to make them explicit and to learn from each, in order to understand the epistemological significance of criticism. I will focus here on just one philosophical theme that is well illustrated by the three texts analysed: the dynamics of knowledge and ways in which this theme is enacted 
in the discourses of criticism/ counter-criticism. I thus leave for future reporting comments related to other themes that emerged as relevant, concerning knowledge (nature, sources, scope, growth, evaluation); truth; reality; and values.

The growth of knowledge emerged from the analysis as an important category, capable of organising others and permeating all three levels of analysis: it acted as a topic for criticism, as a powerful slogan, but also as a condensation of deeper philosophical persuasions. In exploring this theme, I will rely on insights from the philosophy of science, which seemed to throw light on my initially low-connected pool of analytic codes.

The most common philosophical interpretation of the dynamics of knowledge has been the evolutionist one. The logical empiricists held a straightforward, Lamarckian view, according to which knowledge evolves through a uniform process. This view was challenged by a Darwinist understanding of evolution (natural selection of beliefs, of theories, of series of theories so on) or by a spiral model of development (like the one that genetic epistemology puts forward). Still, all these are instantiations of an evolutionist view on knowledge, as epistemologists have been reluctant to subscribe to any kind of non-evolutionist approach. However, some philosophers of science suggested that all this impressive account of the growth of knowledge could be a mere rationalisation of an actually indeterministic and perhaps Brownian dynamic (see, for instance, some of Feyerabend's suggestions - Feyerabend, 1999).

For the purposes of textual analysis, though, the evolutionist vs. non-evolutionist polarity does not provide a framework that could be operationalised without taking sides in doctrinal controversies. Some other descriptors seemed to lend themselves more readily to making explicit the various philosophical interpretations of the dynamics of knowledge. They can be best conceptualised as continua whose middle zones are fuzzy mixtures of attributes:

a. Cumulativeness (new knowledge adds, in a linear or in a more complex way, to an existent corpus of theoretical or procedural knowledge) vs. non-cumulativeness (new knowledge is a 
rupture, a shift from the old definitions of facts/meanings/theories that become thus obsolete). Hence the understanding of the growth of knowledge varies from linearity and continuity (Carnap, 1934) through selection and reinterpretation/ transformation (Popper, 1980; Lakatos, in Lakatos \& Musgrave, 1974; Kuhn, 1970) to rupture, shift, discontinuity (Feyerabend, 1988; Foucault, 1972);

b. Convergence (different researchers or communities of research work together towards the common aim of pushing the boundaries of existing knowledge; even if different, their respective frameworks are mutually translatable) vs. divergence (incommensurability of frameworks, thus research is a rather diverse and discrete, heterogeneous process); midway between the two extremes there is a mixture of convergent and divergent features (Lakatos, in Lakatos \& Musgrave, 1974; Kuhn, 1970) (see also Burbules, 1993);

c. Rationality (knowledge grows according to some rules or criteria of either logical, mathematical, probabilistic, semantic, linguistic, factual, pragmatic or moral relevance; accordingly, research is a rigorous process of gathering and assessing evidence; the rigour is supported by the observance of methodological standards, of logical criteria for argumentation, and/or of requirements related to increasing 'objectivity') vs. non-rationality (which includes, but needs not be confined to, irrationality: research involves not only logic or rigorous reasoning, but also personal taste, emotions, faith, intuition, arbitrary choices) (see Lakatos \& Musgrave, 1974, pp. 177-178);

d. Teleology (research is goal-oriented and its 'fitness to purpose' is the criterion for judging its outcomes) vs. non-teleology (research is a spontaneous development whose 'side-effects' and 'by-products', to use the terms of the teleological approach, are in fact at least as significant as the expected outcomes; therefore, deviance from commonly pursued purposes 
is valuable and necessary).

Having emerged as relevant for the documents analysed in this paper (i.e., I could find there examples that were diverse and consistent enough to allow attempts to generalise), the concepts outlined above were consequently employed in describing the alternative views on the growth of knowledge held by the authors of the three documents and by their critics. Two main possible patterns are largely distinguishable: one characterised by the emphasis on cumulativeness/ convergence/ rationality/ teleology (the so -called "new orthodoxy"); the other, by discontinuity/ divergence/ non-rationality/non-teleology in various degrees and combinations. The discourses corresponding to these approaches are construed around antagonistic series of keywords, the instantiations of which serve as "red flags" of dissent: "unity", "body of knowledge”, "coordination", "reasonable", "validity", "fitness for purpose” versus "difference”, "shift of interpretation", "independence", "emotionality", "deviance. The discourses of the three documents analysed and of the more "radical" strands of their critiques are underpinned by such presuppositions.

For instance, the growth of a cumulative body of knowledge is a central tenet of the criticisms of educational research expressed in the documents analysed. They all insist on the desirability of building a "body" or a "corpus" of knowledge/ research/ evidence, which, even if not necessarily in a linear way, would collate previously fragmented research and would form a solid base for practice and policy-making (Hargreaves, 1996, p. 2, 5, 11; Tooley \& Darby, 1998, p. 13; Hillage et al, 1998, pp. XII, 26-27, 56, 59). Connected to this is the emphasis on replicability and follow-up research (Hargreaves, 1996, p. 2, 7; Tooley \& Darby, 1998, p. 13, 67, 68, 70, 75; Hillage et al, 1998, p. XIII, 26, 57); on systematic reviews or periodical reviews of research that would involve critical examination of the work done to date (Hargreaves, 1996, p.7; Tooley \& Darby, 1998, p. 13; Hillage et al, 1998, p.XII, XIII, 56); on countering the small- 
scaleness of research (Hargreaves, 1996, p.2; Tooley \& Darby, 1998, p. 79; Hillage et al, 1998, p. IX); or on the need for a shared technical language (Hargreaves, 1996, p. 2) and information units (Hillage et al, 1998, p. XIV, 59). Finally, the three documents seem to share a view of the cross-disciplinary comparability of educational research to, for example, medical research (Hargreaves, 1996) or to other social sciences (Hillage et al, 1998, p. XIV, 59). Such a view could be further explored by linking it to philosophical and methodological disputes about the unitary or discrete character of science and about the commensurability of worldviews and paradigms. However, as it is not the purpose of this paper to reiterate these debates, it will refrain from such exploration, despite its potential worthiness.

A convergent view of the process(es) of research transpires from the recommendations that the three documents put forward: national research strategy, framework and fora (Hargreaves, 1996, p. 3,6; Hillage et al, 1998, p. 56) and concentrated funding for fewer, largerscale projects (Tooley \& Darby, 1998, p. 78). These are meant to counter the reign of 'fashion' and the fragmentation of the research community, as well as the isolation of researchers (among themselves and from the communities of practice and of policy-making) (Hargreaves, 1996, p.2; Tooley \& Darby, 1998, p. 79; Hillage et al, 1998, p. X). As a consequence, stronger coordination and dialogue are expected to emerge (hence, the requirements to improve the accessibility of the language of research and to disseminate research through interpretation for different audiences) (Hargreaves, 1996, p. 3, 6; Tooley \& Darby, 1998, p. 77; Hillage et al, 1998, pp.47, 51, 56- 60).

Similarly, the emphasis of the three documents on evidence-based practice (Hargreaves, 1996, p. 1, 3, 4, 7, 8; Hillage et al, 1998, p. XII, XIV, 60) in connection to designing precise ways of ensuring the quality of research (through, for instance, more sustained training in research methodology that would enhance methodological rigour- Hargreaves, 1996, p. 7; Tooley \& Darby, 1998, pp. 14-15, 42-44, 46, 74, 77; Hillage et al, 1998, p. 30, 58) suggests an 
inclination towards celebrating rationality in research and in practice. Systematic and rigorous research would then be assessed on the basis of clear criteria and standards (Hillage et al, p. XIII, $57,58)$ organised in codes of good practice of research, such as scientific soundness, explicitness, rationality and analyticity (Hargreaves, 1996, p. 2, 9, endnotes), avoidance of bias and partisanship (Tooley and Darby, p. 28, 74), or solid argumentation (coherence, consistence, entailment - Tooley and Darby, 1998, p. 53-56, 74).

Finally, research is described as a teleological process, oriented by goals of relevance to practice and to policy (Hargreaves, 1996, p. 1; Tooley \& Darby, 1998, p. 68-69; Hillage et al, 1998, p. XII, XIII, 57, 58) and assessed by its fitness to such purposes. Good research pursues significant ends (as opposed to 'trivia') (Tooley and Darby, 1998, p. 79), and brings with it the benefits of, for instance, 'serving the teaching profession' by 'enhancing effectiveness and satisfaction', 'advancing the professional quality', and 'informing professional practice' through provision of 'evidence about what works' and of 'more accurate means' and 'better ways of doing' (Hargreaves, 1996, p. 1-2).

These observations support the conjecture that the criticism analysed here has been expressed from a standpoint corresponding to the first series of patterns and keywords defined above - cumulativeness/convergence/ rationality/teleology; hence the frequent accusations of "positivism", which implicitly attach to this term a derogatory nuance.

The alternative positions to the one outlined above are far less cohesive, even though it could be argued that many of them share, in various degrees and combinations, some common features such as the inclination towards a relativist and interpretivist stance. The reactions to the kinds of criticisms analysed above came from a diversity of standpoints that can be described and grouped in many different ways (see MacLure's 2003 discussion of 'puritan' vs. 'vernacular' methodologies; also, Oakley's 2000 reinterpretations of the qualitative vs. quantitative dualism; Pring's 2000 discussion of positivist, phenomenological and ethnographic research; 
Hammersley’s, Smith's and Stronach’s, in Hodkinson 1998, debate on three competing paradigms - neo-realism, hermeneutic relativism and postmodernism; Stronach \& MacLure's 1997 distinction between different 'games' of educational research; or Adelmane \& Young's 1985 and Smith's 1989 discussions of the antinomy interpretivism/ empiricism) . Again, it is not the purpose of this paper to discuss in detail such reactions. However, it is necessary to point out at least some of the objections that were raised against the so-called "new-orthodoxy", while leaving a finer-grained account of the philosophical and intellectual traditions that underpin the 'criticisms of criticisms' open for further exploration. The following list will therefore be very eclectic and only meant to give a flavour of the types of counter-arguments that were thrown into the debate.

As described by some of its critics, the "new orthodoxy" would rely on a linear-cumulative view of knowledge growth (Hammersley, 1997, p. 145), on an engineering model of the relation research -practice (Hammersley, 1997, p. 147) and on the concept of 'transparent accountability' of research as a publicly funded activity (Hammersley, 2002, p. 4). An even more radical counter-critique sees the 'new orthodoxy' as built on a series of assumptions characterised as "rampant instrumentalism” (Smith, 2001, p. 187), empiricism /positivism (Standish, 2000), "hard-science" restorationism (Hamilton, 2002, p. 149) or even as 'being based neither on foundational rationality nor on widespread agreement" (but nonetheless dangerous - Hodkinson, 2004, p. 23). Such assumptions would be, for instance: the superiority of research among the various forms of knowledge production (Hodkinson, 2000); the maximisation of "objectivity" to the detriment of values, emotions, "subjectivity" (Hodkinson, 2000, p. 7); a “one-size-fits-all”, "baseball cap science" model of the research - policy relation (Hamilton, 2002, p. 146-147); the centrality of method for assessing research quality (Hodkinson, 2000, p. 2); and the usefulness of agreed criteria lists for judging educational research. As such, the "new orthodoxy" would threat to lead towards: 
- overemphasis on procedural rationality (what works) (Hamilton, 2002, p. 159; Smith 2001, p. 188; Standish, 2000, p.131; Thomas, 1998) in an "audit society" based on new “rituals of verification” (Power, 1997, Hodkinson, 2004, p. 22);

- behaviouristic descriptions of practice (Standish, 2000, p.131);

- brisk, quasi-scientific language (Smith, 2000, p. 142);

- $\quad$ rhetoric and artefact (Smith, 2000, p. 146; Standish, 2000, p. 131);

- 'diktat' and centralisation (Smith, 2001, p. 187; Edwards, Stronach and Hustler, 1999). While coming from a variety of perspectives, the critics of the research "orthodoxy" argue, instead, for either a more balanced and "philosophically reflective" approach to research as "part of the perennial conversation about aims, values or processes" (Pring, 2000b, p. 502; also, Atkinson, 2000); for a new model of the research-practice relation (Furlong and Oancea, 2004; Furlong, 2004; Badley, 2003; Hammersley, 2002, 1997) or, from declared relativist and postmodernist sensibilities, for the acceptance of ambiguity, interpretation, emotionality, irrationality, plurality, disagreement, unexpected, discontinuity and reflexivity for 'telling better stories' in educational research (Hodkinson, 2004, p. 23; Hamilton, 2002; Stronach and MacLure, 1997).

\section{Conclusion}

This paper set out to explore the recent criticisms of educational research along the lines of their targets, rhetorical devices, and philosophical underpinnings in relation to the theme of the growth of knowledge, with no attempts to be exhaustive or to discriminate finally between rights and wrongs in the debate. The idea of analysis that it enacts sees it as an ongoing, recurrent, reflexive process that does not follow a-priori procedures and that alternatively contextualises and abstracts. As such, the analysis integrates qualitative and quantitative techniques in a continuous manner. This combination of phenomenological and realist stances 
from which the analysis started was constantly challenged and refined in the course of the research. The selection of texts and of philosophical themes for this paper was necessarily limited, but even so the analysis did not allow a saturation of the concepts outlined above (cumulativeness/ non-cumulativeness, rationality/non-rationality, convergence/ divergence, teleology/non-teleology). Still, they suggest that what educational research is taken to be varies with the understanding of the dynamics of knowledge; and that on its turn, the definition of educational research bears upon the construction of field identity and professional community as well as upon the links with policy and practice. A further significant question is whether educational research is similar to other types of social research, or education itself has a certain uniqueness that would account for the difficulties of research; in addition, whether the specific situation of educational research created a special case for criticism in Britain in the 1990s (thus justifying its description as a "crisis"), or criticism is simply a constant accompaniment of text production, that is, "wherever any culture produces texts, performances, or events that allow for diverse responses and disagreements, criticism will again break out spontaneously" (Baldick, 1996, p. 206). From criticism as heuristic conversation, as impetus for change, or as regulation mechanism, to criticism as ideological device, as expression of scepticism or as disenchantment discourse, the meanings of criticism shift over the documents published in the 1990s, thus creating a rich and diverse field for future exploration. My current research explores these meanings further, in an attempt to assess the need for criticism where the grounds for certainty are always problematic.

Correspondence: Alis Oancea, Oxford University Department of Educational Studies, 15 Norham Gardens, Oxford OX2 6PY. E-mail: alis.oancea@edstud.ox.ac.uk

\section{ABBREVIATIONS}

AERA - American Educational Research Association BERA - British Educational Research Association 
DfES - Department for Education and Skills, formerly DfEE (Department for Education and Employment)

EPPI-Centre - Evidence for Policy and Practice Information and Co-ordinating Centre (EPPICentre)

ESRC - Economic and Social Research Council

NERF - National Educational Research Forum

NFER - National Foundation for Educational Research

OFSTED - Office for Standards in Education

RAE - Research Assessment Exercise

SERA - Scottish Educational Research Association

TTA - Teacher Training Agency

\section{REFERENCES}

ADELMAN, C. \& YOUNG, M.F.D. (1985) The assumptions of educational research: the last twenty years in Great Britain. In: M. Shipman (Ed.) Educational Research: Principles, Policies and Practices (London and Philadelphia, The Falmer Press)

ALTMAN, D. G. (1994) The scandal of poor medical research, British Medical Journal, 308, pp. 263-284.

ANDERSEN, B. (1990) Methodological Errors in Medical Research: an incomplete catalogue (Oxford, Blackwell Scientific).

ANDERSON, G. L. \& HERR, K. (1999) The new paradigm wars: is there room for rigorous practitioner knowledge in schools and universities?, Educational Researcher, 28, pp. 12-21,40.

ATKINSON, E. (2000) In defence of ideas, or why 'what works' is not enough, British Journal of Sociology of Education, 21, pp. 317 - 330.

BADLEY, G. (2002) The crisis in educational research: a pragmatic approach, European Educational Research Journal, 2, pp. 295-308.

BALDICK, C. (1996) Criticism and Literary Theory. 1890 to the Present (London and New York, Longman).

BALL, S. (1995) Intellectuals or technicians? The urgent role of theory in educational studies, British Journal of Educational Studies, 43, pp. 255-271.

BASSEY, M. (1992) Creating education through research. Presidential Address to the British Educational Research Association, Nottingham, 29 September 1991, British Educational Research Journal, 18, pp. 3-16.

BIDDLE, B. J. (1996) Better ideas: expanded funding for educational research, Educational Researcher, 25, pp. $12-14$.

BILLIG, M. (1996) Arguing and Thinking : a rhetorical approach to social psychology (Cambridge, Cambridge University Press).

BLUNKETT, D. (2000) Influence or irrelevance: can social science improve government? Speech made by David Blunkett, Secretary of State for Education and Employment, to a meeting convened by the Economic and Social Research Council on 2 February 2000, Research Intelligence, pp. 1221.

BRIDGES, D. (1998) Research for sale: moral market or moral maze?, British Educational Research Journal, 24, pp. 593-608.

BRINE, J. (1997) Over the ditch and through the thorns: accessing European funds for research and social justice, British Educational Research Journal, 23, pp. 421-432.

BROWN, M. (1998) Educational researchers in universities: the condition of the workforce. Presidential Address to the British Educational Research Association, University of York, September 1997, British Educational Research Journal, 24, pp. 125-140.

BURBULES, N.C. (1993) Dialogue in Teaching, Theory and Practice (New York, Teachers College Press).

CALDERHEAD, J. (Ed) Educational Research in Europe (Clevedon, Multilingual Matters Ltd).

CARNAP, R. (1934) The Unity of Science (London, K. Paul, Trench, Trubner \& co, Itd).

CARR, W. (2000) Partisanship in educational research, Oxford Review of Education, 26, pp. 437-449.

CARR-HILL, R. (1998) Evidence-based healthcare: flaws in the paradigm?, Journal of the Royal Society of Medicine, 91, pp. 12-14.

COCHRANE COLLABORATION (2002) Preparing, Maintaining and Promoting the Accessibility of 
Systematic Reviews of the Effects of Health Care Intervention. Website www.cochrane.org/software/docs/newbroch.pdf

COURT, C. (1996) NHS Handbook criticises evidence-based medicine, British Medical Journal, 312, pp. 1439-1440.

DIESTERWEG, F. A. W. (1835) Wegweiser zur Bildung für Lehrer und die Lehrer werden wollen (Essen, Vorrede).

DIJK, T. A., VAN (Ed.) (1997) Discourse Studies: a multidisciplinary introduction, Vol. I, "Discourse as structure and process"; vol. II, "Discourse as social interaction" (London, Sage Publications).

DONMOYER, R. (1997) This issue: revisiting the 'Talking <truth> to power' problem, Educational Researcher, 26, pp. 2.

EDWARDS, A., STRONACH, I. \& HUSTLER, D. (1999) Editorial: plain folk and good sense, British Educational Research Journal, 25, pp. 579-582.

EDWARDS, A. (2002) Responsible research: ways of being a researcher. Presidential Address to the British Educational Research Association, University of Leeds, September 2001, British Educational Research Journal, 28, pp. 157-168.

EDWARDS, D. \& POTTER, J. (1992) Discursive Psychology (London, Sage).

EDWARDS, D. (1998) Critique: Reynolds trivializes the complexity both of the means and the ends of effective learning, Research Intelligence, 66, pp. 29-30.

ELLIOTT, J. (1990) Educational research in crisis: performance indicators and the decline in excellence. Presidential Address to the British Educational Research Association, University of Newcastleupon-Tyne, 1989, British Educational Research Journal, 16, pp. 3-18.

ELLIOTT, J. (2001) Making evidence-based practice educational, British Educational Research Journal, 27, pp. 555-574.

EPPI-CENTRE (2003) About the EPPI-Centre. Website http://eppi.ioe.ac.uk/EPPIWeb/home.aspx?page=about_eppi.htm (London, The Evidence for Policy and Practice Information and Co-ordination Centre).

EVANS, J. \& BENEFIELD, P. (2001) Systematic reviews of educational research: does the medical model fit?, British Educational Research Journal, 27, pp. 527-541.

FEYERABEND, P. (1988) Against Method (London, Verso).

FLETCHER, V. (1998) Educational research is dross, says Woodhead, The Times, 23 July.

FORAY, D. \& HARGREAVES, D. (2002) The Development of Knowledge of Different Sectors: a model and some hypotheses. Website www.oecd.org/dataoecd/47/39/2074366.pdf (Organisation for Economic Co-operation and Development, Paris).

FOUCAULT, M. (1972) The Archaeology of Knowledge (London, Tavistock).

FULLER, S. (1999) Making the university fit for critical intellectuals: recovering from the ravages of the postmodern condition, British Educational Research Journal, 25, pp. 583-596.

FURLONG, J. (2004) BERA at 30. Have We Come of Age? Presidential Address to the British Educational Research Association, Heriott-Watt University, Edinburgh, 2003, British Educational Research Journal, 30, pp. 343-358.

FURLONG, J. \& OANCEA, A. (2004) Developing quality criteria for applied and practice based research. Symposium at the British Educational Research Association annual conference, Manchester, September 2004.

GIBBONS, M., LIMOGES, C., NOWOTNY, H., SCHWARTZMAN, S., SCOTT, P. \& TROW, M. (1994) The New Production of Knowledge: the dynamics of science and research in contemporary societies (London, Sage).

GILBERT, G. N. \& MULKAY, M. (1984) Opening Pandora's Box : a sociological analysis of scientists' discourse (Cambridge, Cambridge University Press).

GIPPS, C. V. (1992) National Curriculum Assesment: a research agenda, British Educational Research Journal, 18, pp. 277-286.

GIPPS, C. (1993) The profession of educational research. Presidential Address to the British Educational Research Association, University of Stirling, 1992, British Educational Research Journal, 19, pp. 3-16.

GLASER, B. G. \& STRAUSS, A. L. (1967) The Discovery of Grounded Theory: strategies for qualitative research (Chicago, Aldine Pub.).

GOLDSTEIN, H. \& WOODHOUSE, G. (2000) School effectiveness research and educational policy, Oxford Review of Education, 26, pp. 365-378.

GOODSON, I. (1999) The educational researcher as a public intellectual, British Educational Research Journal, 25, pp. 277-298.

GORARD, S. \& TAYLOR, C. (2003) Editorial - 'In Praise of Educational Research', British Educational 
Research Journal, 29, pp. 619-621.

HAMILTON, D. (2002) 'Noisy, fallible and biased though it be' (on the vagaries of educational research), British Journal of Educational Studies, 50, pp. 144-164.

HAMMERSLEY, M. (1992) The paradigm wars: reports from the front. Review essay, British Journal of Sociology of Education, 13, pp. 131-143.

HAMMERSLEY, M. \& SCARTH, J. (1993) Beware of wise men bearing gifts: a case study in the misuse of educational research, British Educational Research Journal, 19, pp. 489-498.

HAMMERSLEY, M. (1997) Educational research and teaching: a response to David Hargreaves' TTA lecture, British Educational Research Journal, 23, pp. 141-162.

HAMMERSLEY, M. (1997) On 'systematic' reviews of research literatures: a 'narrative' response to Evans \& Benefield, British Educational Research Journal, 27, pp. 543-554.

HAMMERSLEY, M. (2002) The current crisis in educational research, in: M. HAMMERSLEY (Ed) Educational Research, Policymaking and Practice (London, Paul Chapman Publishing).

HARGREAVES, D. H. (1996) Teaching as a Research-Based Profession: possibilities and prospects. Teacher Training Agency Annual Lecture (London, Teacher Training Agency).

HARGREAVES, D. H. (1997) In defence of research for evidence-based teaching: A rejoinder to Martyn Hammersley, British Educational Research Journal, 23, pp. 405-420.

HARGREAVES, D. H. (2003) Education Epidemic: transforming secondary schools through innovation networks (London, Demos).

HARLEN, W. (1994) Developing public understanding of education - a role for educational researchers. Presidential Address to the British Educational Research Association, Liverpool, 11 September 1993, British Educational Research Journal, 20, pp. 3-16.

HILLAGE, J., PEARSON, R., ANDERSON, A. \& TAMKIN, P. (1998) Excellence in Research on Schools. Report no. 74 (London, Department for Education and Employment).

HODKINSON, P. (2004) Research as a form of work: expertise, community and methodological objectivity, British educational Research Journal, 30, pp. 9-26

HODKINSON, P. (2000) The Contested Field of Educational Research: the new research orthodoxy and the limits of objectivity, paper presented at the British Educational Research Association Annual Conference, University of Leeds, September 2000. Website http://www.leeds.ac.uk.educol/documents/00001875.doc.

HODKINSON, P. (1998) (Ed.) The Nature of Educational Research: Realism, Relativism or PostModernism? (Manchester, Manchester Metropolitan University)

HOFSTETTER, R. \& SCHNEUWLY, B. (2000) Sciences of education between disciplinary and professional field. An analysis of the tensions and pitfalls of the process of disciplinarisation, European Educational Researcher, 5, pp. 17-23.

HOMAN, R. (1990) Institutional controls and educational research, British Educational Research Journal, 16 , pp. 237-248.

KEINER, E. (2001) 'Science of Education' between Organisation and Discipline, Evaluation and Research, paper presented at the Philosophy and History of the Discipline of Education Conference, Leuven, October 2001 (Fund of Scientific Research - Vlaanderen).

KUHN, T. (1970) The Structure of Scientific Revolutions (Chicago, London, University of Chicago Press).

LAKATOS, I. \& MUSGRAVE, A. (Eds.) (1974) Criticism and the Growth of Knowledge (Cambridge, Cambridge University Press).

LOMAX, P. (1999) Working together for educative community through research. Presidential Address to the British Educational Research Association, Queen's University Belfast, August 1998, British Educational Research Journal, 25, pp. 5-22.

MACLURE, M. (2003) Discourse in Educational and Social Research. (Buckingham, Open University Press).

MCGAW, B., KOGAN, M. \& TUINJMAN, A. (1996) Educational Research and Development in OECD countries, European Educational Research Association (EERA) Bulletin, 2, pp. 3-12.

MCINTYRE, D. (1997) The profession of educational research. Presidential Address to the British Educational Research Association, Lancaster University, September 1996, British Educational Research Journal, 23, pp. 127-140.

MCNAMARA, D. (1990) The National Curriculum: an agenda for research, British Educational Research Journal, 16, pp. 225-235.

MORTIMORE, P. (2000) Does educational research matter? Presidential Address to the British Educational Research Association, University of Sussex, September 1999, British Educational Research Journal, 26, pp. 5-24.

NISBET, J. D. (1995) Pipers and Tunes: a decade of educational research in Scotland (Edinburgh, 
Scottish Council for Research in Education).

OAKLEY, A. (2000) Experiments in Knowing. Gender and Method in the Social Sciences (Cambridge, Polity Press).

OANCEA, A.E. (2004) With the Benefit of Hindsight? Criticisms of Educational Research over the 1990s, paper presented at the European Conference on Educational Research, Rethymno, Crete, September 2004.

OANCEA, A.E. (2003a) Criticisms of Educational Research over the 1990s, paper presented at the British Educational Research Association Annual Conference, Edinburgh, Heriott-Watt University, September 2003.

OANCEA, A.E. (2003b) Storming the Ivory Tower: Newspapers' coverage of the criticisms of educational research, paper presented at the Scottish Educational Research Association annual conference, Perth, November 2003.

OECD (1995) Educational Research and Development: trends, issues and challenges (Paris, Organisation for Economic Co-operation and Development).

PIRRIE, A. (1997) The new game: professional foul or own goal?, British Educational Research Journal, 23, pp. 565-574.

POPPER, K. R. (1980) The Logic of Scientific Discovery (London, Hutchinson).

POWER, M. (1997) The Audit Society: rituals of verification (Oxford, Oxford University Press).

PRING, R. (2000a) Setting the scene: criticism of educational research, in: Philosophy of Educational Research (London and New York, Continuum).

PRING, R. (2000b) Editorial conclusion: a philosophical perspective, Oxford Review of Education, 26, pp. 495-501.

PUTNAM, H. (1981) Reason, Truth and History (Cambridge, Cambridge University Press)

RANSON, S. (1998) The future of educational research: learning at the centre (report on the 1993 ESRC report), in: J. RUDDUCK \& D. MCINTYRE (Eds) Challenges for Educational Research (London, Paul Chapman Publishing Ltd).

REYNOLDS, D. (1998) Teacher effectiveness: Better teachers, better schools. TTA Lecture, Research Intelligence, 66, pp. 26-29.

SIMONS, H. (1995) The politics and ethics of educational research in England: contemporary issues, British Educational Research Journal, 21, pp. 435-449.

SLAVIN, R. E. (2002) Evidence-based education policies: transforming educational practice and research, Educational Researcher, 31, pp. 15-21.

SMITH, J. K. \& HODKINSON, P. (2002) Fussing about the nature of educational research: the neorealists versus the relativists. Thematic review, British Educational Research Journal, 28, pp. 291-296.

SMITH, J.K. (1989) The Nature of Social and Educational Enquiry: Empiricism vs. Interpretation (Norwood, New Kersey, Ablex Publishing Corporation)

SMITH, R. (2001) Education as a Social Science, paper presented at the Philosophy and History of the Discipline of Education Conference, Leuven, October 2001 (Fund of Scientific Research Vlaanderen, Leuven).

STANDISH, P. (2000) Educational Research: disciplining the profession, paper presented at the Philosophy and History of the Discipline of Education Conference, Leuven, October 2000 (Fund of Scientific Research - Vlaanderen).

STRAUSS, A. L. \& CORBIN, J. M. (1998) Basics of Qualitative Research: techniques and procedures for developing grounded theory (Thousand Oaks, London, Sage Publications).

STRONACH, I., ALLAN, J. \& MORRIS, B. (1996) Can the mothers of invention make virtue out of necessity? An optimistic deconstruction of research compromises in contract research and evaluation, British Educational Research Journal, 22, pp. 493-509.

STRONACH, I. (2001) Editorial, British Educational Research Journal, 27, pp. 123-124.

STRONACH, I. \& HUSTLER, D. (2001) Editorial, British Educational Research Journal, 27, pp. 523-525.

STRONACH, I. \& MACLURE, M. (1997) Educational Research Undone: the postmodern embrace (Buckingham and Philadelphia, Open University Press).

SYLVA, K. (2000) Editorial, Oxford Review of Education, 26, pp. 293-297.

THOMAS, G. (1998) The myth of rational research, British Educational Research Journal, 24, pp. 141162.

TOOLEY, J. \& DARBY, D. (1998) Educational Research: A critique. A survey of published educational research. Report (London, Office for Standards in Education).

WAGNER, J. (1993) Ignorance in educational research: or, how can you not know that?, Educational Researcher, 22, pp. 15-23. 
WELLINGTON, J. J. (2000) Educational Research. Contemporary Issues and Practical Approaches (London and New York, Continuum).

WOODHEAD, C. (1998) Foreword, in: J. TOOLEY \& D. DARBY (Eds) Educational Research: A critique. A survey of published educational research (London, Office for Standards in Education).

WRIGLEY, J. (1976) Pitfalls in educational research, Research Intelligence, 2, pp. 2-13.

YATES, L. (2004) What Does Good Education Research Look Like? : Situating a field and its practices. (Maidenhead, Berks., Open University Press). 
Alis Oancea, University of Oxford

\section{Criticisms of Educational Research: Key topics and levels of analysis}

\section{Abstract}

The article is an exploration of the meanings and worthiness of criticism as a significant phenomenon in the evolution of educational research over the 1990s. While drawing on an overview of the vast amount of documents expressing criticisms of educational research in the United Kingdom, Western and Eastern Continental Europe and the United States of America, it summarizes the findings of a study based on the analysis of some of the most influential texts that criticised educational research in the United Kingdom, during the mid-1990s: Hargreaves (1996), Tooley \& Darby (1998), Hillage et al. (1998). An understanding of the targets, sources, solutions and actors that are characteristic for the recent criticisms of educational research is proposed, together with an exploration of the rhetorical devices employed in expressing criticism and of some of the philosophical themes that underpin the recent debates.

Correspondence: Alis Oancea, Oxford University Department of Educational Studies, 15 Norham Gardens, Oxford OX2 6PY. E-mail: alis.oancea@edstud.ox.ac.uk 